\title{
On Dokuzuncu Yüzyıl Türk Romanında Acıma veya Merhamet Uyandıran Bir Durum Olarak Yoksulluk*
}

\author{
Ahmet Ferhat ÖZKAN \\ Arş. Gör. Dr., Necmettin Erbakan Üniversitesi, Sosyal ve Beşerî Bilimler Fakültesi, Türk Dili ve \\ Edebiyatı Bölümü, Konya, Türkiye \\ afozkan@erbakan.edu.tr
}

\begin{tabular}{|c|c|}
\hline Makale Bilgileri & $\ddot{O Z Z}$ \\
\hline $\begin{array}{l}\text { Makale Geçmişi } \\
\text { Geliş: 13.11.2020 } \\
\text { Kabul: 07.04.2021 } \\
\text { Yayın: } 30.06 .2021 \\
\text { Anahtar Kelimeler: } \\
\text { Merhamet, Acıma, } \\
\text { Yoksulluk, On } \\
\text { Dokuzuncu Yüzy1l } \\
\text { Türk Romanı. }\end{array}$ & $\begin{array}{l}\text { İlk Türk romancıları, kadının toplumdaki konumu veya Batılılaşma gibi konularda birbiri ardına tezli romanlar yazmışlarsa } \\
\text { da gündelik hayattaki yoksulluk, bu dönem yazarları için başat bir problem olamamıştır. On dokuzuncu yüzyılda Türk } \\
\text { romancılığının hem eser sayısı hem de okur üzerindeki etkisi bakımından en önemli yazarı Ahmet Mithat, yoksulluğu } \\
\text { Osmanlı coğrafyasından daha çok Avrupa'ya veya Osmanlı coğrafyasındaki gayrimüslimlere yakıştırır. Ekonomiye dair } \\
\text { Türkçedeki ilk kuramsal iktisat metinlerini de yazan Ahmet Mithat, açlıkla ve evsizlikle sonuçlanan bir yoksulluk yerine } \\
\text { orta sınıf bireyin daha çok para kazanması ile ilgilenir. Halit Ziya ise realist tavrının da bir sonucu olarak yoksulluğu daha } \\
\text { çarpıcı bir şekilde işler. Yoksulluk ve Türk romanı bağlamındaki ikinci bir tespit ise yoksulluğun birey ve toplum } \\
\text { üzerindeki olumsuz etkileri konu edildiğinde, bu durumun okurda uyandırdığı duygunun saiklerinin sorgulanmasının } \\
\text { gerekliliğgidir. Bu noktada merhamet ve acıma duyguları arasında bir ayrım yapıllması hem romanların tasnifi hem de bu } \\
\text { dönemin düşünsel nitelikleri bakımından oldukça önemlidir. Bunun ardından, on dokuzuncu yüzyıll Türk romanında } \\
\text { yoksulluk karşssınnda doğan duygunun kaynağını dinden alan bir merhameti mi yoksa Aydınlanma değerlerine dayanan bir } \\
\text { acıma duygusunu mu doğurduğu sorusu sorulmalıdır. Bu nedenle, bu çalışmada öncelikle politik bir tavrı da işaret eden } \\
\text { bu iki duygu arasındaki farka odaklanılacak, bu iki duygunun toplumsal tarihleri incelenecek, daha sonra ise on dokuzuncu } \\
\text { yüzyıl Türk romanında yoksulluk ve bu yoksulluğun hangi duyguya, başka bir deyişle hangi değerler dizgesine tekabül } \\
\text { ettiği sorusunun cevapları aranacaktır. }\end{array}$ \\
\hline
\end{tabular}

\section{Poverty As a Pity or Compassion Evoking Matter in the 19th Century Turkish Novel}

\begin{tabular}{|c|c|}
\hline Article Info & ABSTRACT \\
\hline $\begin{array}{l}\text { Article History } \\
\text { Received: } \quad 13.11 .2020 \\
\text { Accepted: } \quad 07.04 .2021 \\
\text { Published: } 30.06 .2021 \\
\text { Keywords: } \\
\text { Compassion, } \\
\text { Pity, Poverty, } \\
\text { 19th Century Turkish } \\
\text { Novel. }\end{array}$ & $\begin{array}{l}\text { First Turkish novelists had written "novels with thesis" one after another on social statues of women, or Westernisation. } \\
\text { However, poverty in daily life could not become a primary matter for those writers. Ahmet Mithat, who is the most } \\
\text { important author in terms of numbers of his publications and also of his effect on society, associates poverty with Europe } \\
\text { or non-muslim people of Ottoman lands, rather than the Ottoman people who live in Istanbul. As an author of fist } \\
\text { theoretical books on economy in Turkish, he is more interested especially in middle class men earning more money instead } \\
\text { of poverty that ended with hunger and homelessness. On the other hand, in the novels of Halit Ziya, as a consequence of } \\
\text { his realist attitude, there can be found poverty scenes written in a more striking way. As for the second observation on the } \\
\text { context of Turkish novel and poverty when the negative effects of poverty on a single person or on a society are covered } \\
\text { in the story, it is then necessary to question what motives and reasons evoke feelings in readers. At this point, a distinction } \\
\text { between pity and compassion is important not only for the categorisation of the novels but also understanding the } \\
\text { intellectual characteristics of this period. Subsequently, the question rises whether the emotion evoked by poverty is the } \\
\text { compassion based upon religious virtues or the pity based upon the values of Enlightment. Therefore, this study will focus } \\
\text { primarily on social histories and the differences between these both emotions whose each one indicates a political attitude. } \\
\text { Afterwards the answers to the questions of the poverty in 19th century Turkish novel and with which emotions and set of } \\
\text { values this poverty is corresponded will be sought. }\end{array}$ \\
\hline
\end{tabular}

Atıf/Citation: Özkan AF. (2021). On Dokuzuncu Yüzyıl Türk Romanında Acıma veya Merhamet Uyandıran Bir Durum Olarak Yoksulluk, Medeniyet ve Toplum Dergisi, 5(1), 48-65.

"This article is licensed under a Creative Commons Attribution-NonCommercial 4.0 International License (CC BY-NC 4.0)"

*Bu makale, Doç. Dr. Ertan ENGİN danışmanlığında tamamlanan “Türk Romanında Duygular (1872-1901)" başlıklı doktora tezinden türetilmiştir. 


\section{GİRIŞ: ACIMA VE MERHAMET AYNI DUYGULAR MIDIR?}

Ahmet Hamdi Tanpınar, XIX. Asır Türk Edebiyatı Tarihi'nde (2008) yeni bir ahlakın doğuşunu Ahmet Mithat'ın Letâif-i Rivâyat'ında yer alan Mihnetkeşan'ını örnek vererek gösterir. Ona göre, Mihnetkeşan'da yazar, hayat kadınlarını devrin "görenek"lerine uyup yargılamak yerine onlara acıma duygusuyla yaklaşır ve böylece "Acıma hissi, kökünü dinden alan bir ahlakın ötesine geçer” (s. 266). Aynı şekilde, Mehmet Kaplan da (2000), Samipaşazade Sezai'nin "Pandomima"sını tahlil ederken bu hikâye ile Batı'dan bir duygu ithal edildiğini söyler: "Günlük hayatta rastlanılan alelade bir insana karş1 duyulan beşeri alaka ve acıma duygusu da Türk edebiyatına Batı'dan gelmiştir” (s. 24-25). Bu iki alıntıya dayanarak Türk edebiyatında yeni türlerle birlikte yeni bir duygunun da görülmeye başladığını söylemek mümkün görünse de acıma ve merhamet duyguları arasındaki ontolojik fark üzerine yoğunlaşmak hem yukarıdaki yargılarının kapsamını daha anlaşılır kılacak hem de on dokuzuncu yüzyıl Türk romanında görülen yoksulluk durumlarının anlamlandırılması için yararlı olacaktır.

"Acıma duygusu, bu duygunun etkisiyle yapılan iyilik, lütuf" (Çağrıcı, 2004, s. 184) anlamındaki merhamet, kaynağını Tanrı'dan alır. "İslâmî kaynaklarda merhamet kavramı genellikle 'rahmet' kelimesiyle ifade edilir. Ancak Türkçede merhamet hem Allah'a hem insanlara, rahmet ise özellikle Allah'a nisbet edilerek kullanılır" (s. 184). Bu nedenle merhamet dinî bir erdem olarak görünür ve "acıma" duygusunun saf halinden ötesini ifade eder. Aristoteles'te ise acıma duygusu (eleos) birtakım koşullara bağlıdır. "Acıma, yıkıcı ve acı verici bir kötülüğün, bunu hak etmemiş bir kişinin başına geldiğini gördüğümüzde, bizim ya da bir arkadaşımızın başına da gelebileceğini, dahası bunun çok yakında olabileceğini beklediğimizde duyduğumuz acı hissi olarak tanımlanabilir." (Aristoteles, 2000, s. 116). Antik Yunan'daki bir diğer acıma eylemi ise oiktos'dur. David Konstan, antik Yunan metinlerinde acıma duygusunun izini sürdügü kitabı Pity Transformed'da (2001) bu iki eylemin birbirleriyle eş anlamlı sayılacak kadar yakın anlamlı olmasına rağmen, ikincisinin anlamının "yas"a daha yakın olduğunu, daha şiirsel ve daha seyrek bir kullanımının olduğunu belirtir (s. 53). Konstan, Yunancada bu iki kelimeyle karşılanan “acıma”nın Latince karş1lığının misericordia olduğunu ekler (s. 5). Diğer yandan Yunancanın ön eklerinden sun- (zamanla sym- haline dönüşmüştür) önüne geldiği fiile "birlikte yapmak" anlamı katmaktadır ve Yunancanın klasik döneminden itibaren sumpatheia bugünkü anlamına benzer bir kullanımla dolaşıma girmeye başlamıştır (s. 58). "Pathe'yi birlikte hissetmek" anlamı veren ve modern İngilizcedeki sympathy (sempati) kelimesine öncülük eden bu kelimenin Latince karşıllğı, yine "birlikte yapmak" anlamını veren com- öneki ve pathos'un Latince karşılığını (-patheia) oluşturarak İngilizcede compassion (merhamet) kelimesini doğurmuştur (s. 13). Latincede bu kelimenin ikinci yüzyılda Hıristiyanlık savunucusu Tertullian tarafından tanıtıldığını söyleyen Konstan, fiil olan compati sözcügüne (merhamet etmek) Yeni Ahit'in Latinceye ilk çevirisi sırasında rastlanıldığını ifade eder (s. 58). Böylece, merhametin tıpkı İslam literatüründe olduğu gibi Batı'da da dinsel bir temeli olduğu görülmektedir. Diğer yandan, "sempati" kelimesiyle anlam yakınlı̆̆ bulunan "empati” sözcüğü ise yapma bir kelimedir. "Sanat eseriyle bütünleşme" anlamındaki einfühlung'a karşılık olarak empathy kelimesini Vernon Lee'nin ilk kullanımından (Lee ve AnstrutherThomson, 1912) sonra anlam kaymasını uğrayarak "ötekinin tecrübesinin hayalî inşası" anlamında dolaşıma girmiştir (Ratcliffe, 2008, s. 8). Ratcliffe'in Nussbaum'dan alıntıladığı ifadeyle, bu yapma kelimede "deneyimin özel bir değerlendirilmeye tabii tutulmadan inşa"sı (2001, ss. 301-302) mevcutken, sempati (sympathy) kavramı acıma duygusunun yoğunlukla hissedildiği bir deneyimi işaret eder (Ratcliffe, 2008, s. 8).

Acıma ve merhamet sözcükleri arasındaki köken ve kaynak bakımından farklılık, kavramların anlamsal derinliklerine de yansımıştır. Spelman (1997), merhameti (compassion), "başkaları ile" acı çekmek, acımayı ise "başkaları için" acı çekmek olarak ayırır (aktaran Ahmed, 2015, s. 58). Hannah Arendt, Amerikan ve Fransız Devrimleri üzerinden devrim fikrinin öncü değerlerini tartıştı̆̆ kitabı Devrim Üzerine'de, (2017) acıma ve merhamet arasındaki ontolojik farka da değinir. Arendt, acımanın 
saf bir duygu/duygulanım, merhametin ise bu duygulanımın etkisiyle eylemi zorunlu kılan başka bir duygu olduğunu savunur. "[A]cıma bir etkilenim, merhamet ise bir duyarlılıktır" (Arendt, 2017, s. 115). Fakat Arendt'e göre acımanın yol açması gereken etkinlik merhamet değil, dayanışmadır. "Merhamet, acımanın başka bir yola sapmış hali olabilir; fakat onun alternatifi dayanışmadır" (s. 114). Arendt, merhameti yukarıdan aşağıya doğru hareket eden bir duygu olarak görür ve ona göre bu durum eşitlikçi bir devrim fikriyle uyuşmaz. Arendt'in görüşleriyle birlikte "acıma"nın sadece kişisel bir duygu veya duygulanım olmakla kalmayıp sosyal bir yönü olduğu biraz daha belirginleşir. Nitekim bireyin, öteki ile niçin ilgilendiği, eğer ilgileniyorsa kendisini neden ilgilenmek zorunda hissettiği, bireyin dünya görüşü/algısına dair önemli veriler sunacaktır.

Tanpınar'ın ve Mehmet Kaplan'ın acıma hissini bir yenilik olarak görmelerine bu nedenle tekrar dönmek gerekir. Elbette Divan edebiyatında da acıma duygusu vardır. Sevgili karşısında kendisini kul, geda veya sevgilinin eşiğinde yatan köpek gibi düşkün şekilde konumlandıran âşığın bir yandan kendisine acıdığı bir yandan da merhamet dilendiği bir gerçektir. Fakat âşığın çoğunlukla isteyerek kendisine biçtiği rolden dolayı yine kendisine acıması, deyim yerindeyse, bir tür mazoşizm olarak da değerlendirilebilir. Divan edebiyatında mâşuğun acımasızlığının ve âşığın kendisine duyduğu acımanın (veya kendisini acınacak durumu düşürmesinin) ekonomik şartlardan veya toplumsal statüden dolayı oluşan acıma duygusundan çok farklı olduğu bir gerçektir. Bununla birlikte, Tanzimat romanının en önemli düşünsel ve kültürel kaynağı olan İslam dininin "merhamet dini” şeklinde kültürel kodlamasını destekleyen pek çok referans bulunmaktadır. Kuran'da merhamet kavramının yüz on dört kez tekrar edilmesinin yanı sıra Allah'ın "rahman" ve "rahim" sıfatları iki yüz altmış ayette hatırlatılmıştır (Çağrıc1, 2004). Hadisler, merhameti destekleyen ve teşvik eden bir başka önemli kaynaktır (Ardıç, 2002). Bu bakımdan Osmanlı gündelik hayatında ve şer'i hukukta baskın öge olan İslam dininin merhamete bakışı oldukça açıktır.

Jale Parla'nın Tanzimat romanının epistemolojik temellerini incelediği kitabı Babalar ve Oğullar' da (2003) vurguladığı üzere epistemolojisi İslam ahlakı üzerinde yükselen Tanzimat romanında görülen acıma duygusu, eğer bu anlayış temel alınırsa, dinî bir vecibe olarak kabul edilecek ve bir duygudan değil, bir görevden bahsedilecektir. Ne var ki Tanzimat'la birlikte bu episteme'nin sinırları daha geçirgen bir hale gelmiş, toplum yeniden yapılanmış ve acıma duygusunun "Allah rızası" ile açıklanmadığı; Aydınlanma değerlerinden beslenen, insan merkezli bir yapılanma doğmuştur. Bu anlamda, Osmanlı düşünsel hayatı sekülerleştikçe merhametin yerini saf bir acıma duygusuna bırakıp bırakmadığ1, merhametin sekülerleşip acımaya dönüşüp dönüşmediği incelenmeye değer bir konudur. Arendt (2017); Rousseau ve Robespierre sayesinde “acıma”nın Fransız Devrimi'nin temel değerlerinden biri haline geldiğini ve "bir inayet dini olan Hıristiyanlığın" iktidarındaki Kilise dışında merhametin toplum dinamiği olamadığını belirtir (s. 90). Bu anlamda, Tanzimat romanında acıma uyandıran durumlar ve bunların merhamete hangi kaynaklardan hareketle dönüştügü veya dönüşmediği önemli bir soru olarak belirir. Örneğin, Osmanlı esaret sistemine en güçlü eleştiriyi getiren Sergüzeşt, acıma/merhamet duygularının dinî bağlamdan kopmasına dair sunduğu önemli verilerle dikkat çeker. Kötü muamele gördüğü evden kaçan Dilber'i saklayan yaşılı kadın, Dilber'i satın almak için her ne kadar "Cenab-1 Hak çocukların günahlarını affettiği gibi, hanımları da kusurlarını affetmelidir" (Sezai, 2017, s. 37) diyerek Dilber'i satın almayı teklif etse de, tüm dinî atıfı bundan ibarettir. Yaşlı kadın, Dilber'in gördüğü muameleyi önlemek, onun azat edilmesini sağlamak için başka herhangi bir dinî referans kullanmaz. Anlatıcı ise bu konuda daha keskindir: "İhtiyarlara tazim, kadınlara hürmet, çocukları himayet, insaniyetin, medeniyetin vicdana tevdi ettiği bir vazife-i mukaddese olduğunu bilmeyen bu murdar vahşi [...]" (s. 38). Bu cümle, Aydınlanma değerlerinin veciz bir ifadesi olarak da okunabileceği, Todorov'un Aydınlanma felsefesinin temelinde bulduğu eşitlik ilkesini açıladığı cümle ile kıyaslandığında daha anlaşı1ır hale gelir. Todorov'a göre (2019) Aydınlanma ile ortaya çıkan evrensellik fikri, kutsaldan arınmış bir insan haklarını da doğurur: "Kadınlar, yasa karşısında erkeklerle eşit olmalıdır; bir insanın özgürlüğünün devredilmesi asla meşru olamayacağı için kölelik ortadan 
kalkmalıdır; yoksullar nüfuz sahibi olmayan kişiler, marjinaller onurlu bir şekilde tanınmalı ve çocuklar birey olarak görülmelidir" (s. 15).

On dokuzuncu yüzyıl romanında acımanın saiklerindeki değişimi gösteren diğer bir örnek, devrinde oldukça popüler olan ve romanlarında hep acıma duygusunun baskın olduğu olaylar ve acınası karakterler yaratan Mehmet Celal'in en bilindik romanlarından Bir Kadının Hayatı'nda (2001) bulunabilir. Romanın baş karakterlerinden Ziya Bey, babasının on dört yaşındaki Nilüfer'i odalık almasını kabullenemez. Ziya Bey, "artık Allah'tan bile imdat talep etmeye cesaret edemiyor" (s. 62) dediği Nilüfer'e yardım etmek ister. Bu motivasyonun sebebi ve sonucu ise dikkate değerdir: "İnsaniyetin ulviyetini muhafaza etmek için, icap ederse, babama da isyan ederim!" (s. 62). Ziya Bey, babasının Nilüfer'i odalık alma isteği karşısında Nilüfer'e duyduğu "acıma”yı "merhamet”e dönüştürmek için “Allah rızası"nı referans gösteremez. Engellemek istediği eylemin İslam'a uygunsuzluğundan da bahis açamaz, çünkü cariyelik ve odalık sistemi, köklerini şer'i uygulamalara dayanan örfi ahlaktan almaktadır. Bu durumda, acımanın edebî türlerde etkisini gösteren Batılı bir tema olmakla kalmayıp yeni bir duyarlık olduğu gerçeği de belirginleşmiş olur. Bu duyarlığın kaynağı ise Tanzimat sonrası Batılılaşmayla Osmanlı düşünsel hayatına giren tüm yenilikler gibi Tanzimat'ta aranmalıdır.

Her ne kadar Ziya Paşa ve Namık Kemal gibi Jön Türkler Tanzimat'la birlikte şeriatın esaslarından uzaklaşıldığına ve şeriatın esasları uygulansa zaten bir tanzime gerek duyulmayacağını söyleseler de onlara rahatsızlık veren hususlar, bu ikiliği daha görünür kılmaktadır. Namık Kemal Íbret'teki bir yazısında ${ }^{1}$ "Biz ne zamana kadar..." diye başladığı bir tiratta erkeklerin karılarını dövmesinden, annelerin kızlarını esir kız gösterir gibi bir görücüye gösterdikten sonra kızın onayını almadan evlendirmelerinden yakınır (Aktaran Fındıkoğlu, 1999, s. 652). Namık Kemal, bu sorulardan sonra bir uyanış çağrısı yapar. "İntibah! İntibah! İçinde bulunduğumuz sefine-i arzın arası kesilmez intizamsız hareketlerle bizi mehleke-i iğtiraka düşüyoruz, sonra rüzgâra kabahat buluyoruz" (s. 652). Namık Kemal'in “intibah" çağrısının, -her ne kadar İntibah romanında olmasa da- Tanzimat romanında karşıllı̆̆ını bulduğu, kişisel hürriyete, (yeni) haklara ve böylece acımaya dair yeni bir bilincin geliştiği açıktır. Elbette bu bilincin kökenleri edebi alanda Şinasi'ye dek uzanır. Şerif Mardin (2013), Şinasi'nin Batı düşüncesinin derinliklerini anlayabilmiş ve o düşüncenin laikliğini kavrayabilmiş ilk düşünür olduğunu söyler (s. 85). Mardin'e göre Aydınlanma ile birlikte doğan "hürriyet" kavramı, "kitap kültürü" ile yakından ilişkilidir. "Matbaanın icadından sonra, kitap, eskiden hâkim olan 'şahıstan şahısa geçen bilgi' sürecinin yerine kaim olduğu oranda, 'tenkid', kurallarını otoritenin yerine 'sebep vererek anlatma' kültürünü yerleştirmiştir” (s. 84). Şinasi'nin Tasvir-i Efkâr'1 kurmuş olmasını bu sebebe bağlayan Mardin'in bu fikrine, Şinasi'nin ve ardından gelen isimlerin, edebi dili halk diline yaklaştırma ve böylece kitabı (yazıyı) halkın dolaşıma sokmak için gösterdikleri çabayı da eklemek gerekir. Mardin'in yukarıda alıntılanan ifadesini destekleyen temel kaynaklardan biri olarak gösterilebilecek, Marshall McLuhan'ın Gutenberg Galaksisi (2014) adlı çalışması, “yeni insan”ı kitap kültürünün yaratmış olduğunu ayrıntılarıyla anlatır. Matbaa, sadece kitapların çoğalmasını değil, kozmik bütünlükten kopuşu yeni değerlerin yayılmasını hızlandırmıştır. Başka bir ifadeyle "matbaanın Avrupa'da kullanılmaya başlanmasıyla birlikte ortaya çıkan yazılı kültürün taşıdığ 1 mekanist, modern dünya görüşü ise insanı kozmik bütünlügünden koparmış, farklı bir varlık yapısına uygun değer yapıları geliştirmeye başlamıştır." (Kalın, 2016, s. 75) İnsan bilgisinin üretimi olan kitap ile birlikte insanlık tarihinde, Foucault'nun "Kartezyen an" olarak adlandırılan kırılma, matbaa ile birlikte yaşanmış ve "evvelden kendilik kültüründen neşet etmiş olan değer yapıları yeni baştan tasarlanmıştır" (s. 85). Bu kozmik kopuşun, duygular -ve acıma/merhamet bağlamında- sonucu ise etikte yarattığı merkez kaymasıdır. "Kartezyen an"dan sonra "insanla hakikatin bilgisi arasında etik bir dolayım yoktur; hâlihazırda verili insan doğası nesnenin hakiki bilgisini hiçbir ahlakî/ruhani dolayıma maruz kalmadan

1 İbret, 1872 Teşrin-i Sani 19, No. 56. Aktaran: Fındıkoğlu, a.g.y., s. 652. 
kazanıp deneyimleyebilecek teçhizatla donatılmıştır" (s. 90).

Acıma ve merhamet bağlamında asıl önemli olan, Şinasi’nin Aydınlanma değerleri ile ilişkisidir. "Aydınlanma devri düşüncelerinin kişisel 'hürriyet'le ilgili olduğundan şüphe edilmez. Şinasi'nin de 'hürriyet' konusundaki düşüncelerini Fransa'da geçirdiği devrede Aydınlanma devri yayınlarından ve kişiye özellikle önem tanıyan romantizmden aldığını tahmin ediyoruz" (Mardin, 2013, s. 85). Bedri Mermutlu (2004) ise Şinasi'nin "akıl” kavramı üzerinde yükselen fikirlerini açıklarken "epistemolojik kopuş" (1985, s. 356) sonucu oluşan yeni değerler manzumesine değinir. "Bilgisizlik, taassup, zulüm, esaret, birbirini doğuran şeylerdir. Bunların zıddı olan bilgi, medeniyet, hüsn-i tedbir, özgürlük ise yine birbirine bağlı değerler manzumesidir" (s. 240). Münif Paşa gibi bir devlet adamının da girişimiyle kurulan Cemiyet-i İlmiye-i Osmaniye Batı' daki sadece teknik değil beşeri gelişimini de yakından takip etmektedir ve Aydınlanma devri yazarlarının makalelerinden oluşan tercümeleri bir araya getirir: Muhaverat-ı Hikemiye (Mardin, 1991, s. 48). Böylece, Tanzimat'1n kabaca "Gâvura gâvur denmeyecek" gibi bir genelleştirmeyle özetlenen haklar ve özgürlük bahsinin, gayrimüslimlere eşitlik vadeden bir sistem getirmekten daha çok, insanın dünyadaki varoluşuna ve devlet karşısındaki duruşuna dair yeni bir duyarlık eklediği de somutlaşmış olur. Bu nedenle, Hannah Arendt'in Fransız Devrimi ve acıma duygusu arasında kurduğu bağlantıya Osmanlı siyasi ve düşünsel hayatında bir devrim niteliğinde sayılan Tanzimat ile acıma arasındaki bağlantıyı da eklemek gerekir. Bu noktada Ziyaeddin Fahri Fındıkoğlu'nun (1999) Tanzimat'ın doğurduğu zihinsel yarılmaya dair söylediklerini hatırlamak yerinde olacaktır. Ona göre, Tanzimat'ın "kanun" mertebesine ulaşamamış yarı-sekülerliğine rağmen sonrasında görülen "beşeri bir illiyet esası"nın temelleri, Tanzimat'ta ve Tanzimat döneminde tecrübe edilen değişimlerdedir (s. 657). Bu anlamda, insanın kaderi ve böylece yoksulluk ilahi bir takdir olarak görülmek yerine "beşeri bir illiyet esası"na göre yeniden değerlendirilmiş, hürriyetinin temel bir hak olduğu kabul edilmeye başlanmış ve refahının eşitsiz dağılımı romancıların -zaman geçtikçe- daha önemli hale gelen bir sorunu haline gelmiştir. Tüm bunlar, "acıma"nın dinî epistemolojiyle merhamete dönüşümünden daha fazlasını ifade etmiş ve acıma duygusunun yeniden keşfini beraberinde getirmiştir. Diğer yandan, bu keşif, Batı düşüncesinde sekülerleşen acıma duygusunun, hatta duygudaşlığın (sempati) keşfidir.

Natan Sznaider, merhametin tarihsel ve sosyolojik boyutlarını incelediği "The Sociology of Compassion" [Merhametin Sosyolojisi] adlı makalesinde (1998) Orta Çağ boyunca Kilise'nin kontrolünde olan merhametin, tıpkı Hannah Arendt'in söylediği gibi, siyasi veya toplumsal bir boyutu olmadığını ifade eder. Ona göre, "Orta Çağ’ da merhamet düzenli bir yardımlaşmayı sağlayamamıştır. Başkalarına yardım etmek bir Hıristiyanlık prensibi olan agape temelinde yükselmiştir” ( s. 122). Agape'nin doğaçlama, koşulsuz ve gerekçesiz bir sevgi olduğunu söyleyen Szanider, Hıristiyanlığın temel düsturlarından olan "Komşunu da kendini sevdiğin gibi sev" ilkesinin "toplumsal bir merhamete ve insanoğluna dair sevginin [insan sevgisi] seküler görünüşü” yle karşılaştırılamayacak denli farklı olduğunu ifade eder. Orta Çağ hayırseverliği tüm insanlara yönelik değildir ve herkesin mutluluğunu sağlamaya çalışmaz. Bu yönüyle modern "humanism"den ayrılır. "Acıyı hafifletir, fakat onu sonlandırmayı aklına bile getirmez. "Düşüş”ün ve insanoğlunun günahkârlığı gereği bu dünyada acının kaçınılamazlığını ve adaletini bir ön kabul olarak varsayar. Bu yüzden, toplumsal merhametin temel dayanağı olan bir Aydınlanma prensibi olarak 'insan sevgisi', 'komşu sevgisi'nden ayrılmalıdır” (s. 123). Bu nedenle, Mehmet Kaplan'ın merhametin Batı'dan alınan bir tema olduğu yönündeki ifadesini yerli yerine oturtmak şarttır. Orta Çağ Batı'sından veya Hıristiyan etiğinden değil, kozmolojik kopuşu gerçekleştiren Batı'dan alınan modern değerlerin bir parçası olarak alınan duygu, merhametten daha çok acıma olarak adlandırılmalıdır.

Aydınlanma düşüncesinin temel özelliğinin dışsal bir otorite tarafından dayatılan vesayetin yok edilmesi olduğunu söyleyen Todorov, böylece insanın belirli bir özerklik ve özgürlükle birlikte yeni bir erek de kazandığını belirtir. Özgürleşmiş beşerî eylemlerin ereği de dünyevileşmiştir: “Artık Tanrı’yı değil insanları hedefler. Bu anlamda Aydınlanma düşüncesi bir hümanizm veya başka bir deyişle insan 
merkezciliktir. İlahiyatçıların istediği gibi artık Yaratıcı'nın aşkı uğruna yaratıklara duyulan aşkın feda edilmesi gerekmez: Başka insanları sevmekle yetinilebilir" (Todorov, 2019, s. 15). Böylece, başka bir insanın durumunu önemsemenin, Hıristiyanlıkta caritas'tan İslam'da ise hayırseverlik ile Allah'ın rızasını kazanmak arasında uzanan bir yelpazeden uzaklaşıp daha dünyevi bir nitelik kazandığı görülür. Todorov, Aydınlanma ile birlikte insan sevgisinin artık ilahi bir gerekçeye ihtiyaç duymadığını söyleyerek caritas'ın yok oluşunu şu örnekle açıklar: "Bir konukseverlik edimini hayal ederken Franklin şöyle bir yorumda bulunur: 'Evimi size İsa'ya sevgim dolayısıyla değil, size sevgim dolayısıyla açıyorum"” (s. 74).

"Bir insanın hadd-i zatında ne salahiyeti olabilir ki diğerini kendisine hizmetkâr addedebilsin?"2 (Sarıdoğan, 2014, s. 285) diyen Ahmet Mithat'ın bu sorusunun, bu nedenle, Aydınlanma düşüncesinin doğal sonuçlarından biri olduğu söylenebilir. Yine Todorov'un Rousseau'nun Yeni Heloise'sindeki Julie'sinden ödünç aldığı ifade, Ahmet Mithat'ın sözleriyle anlamlı bir paralellik arz eder: “'İnsan, sadece başkalarına bir araç olarak hizmet etmek için fazlasıyla asil bir varlıktır'” (s. 74). Her ne kadar Ahmet Mithat'ın yazı hayatının ilk yıllarında dile getirdiği bu görüşü zamanla yumuşayıp değişse de Tanzimat romanında insanın yeryüzündeki konumu yeni bir sorunsal olarak belirir. Bu sorunsal bireyin “öteki” ile kurduğu duygu ortaklığı temelinde yükselir.

\section{ACIMANIN KAYNAKLARI}

Türk romanının ilk örneklerinde acıma duygusu uyandıran başlıca üç konu bulunur. Bunlardan ilki esaret meselesi, diğeri yoksulluk ve onun yol açtığı sorunlardır. Acıma uyandıran üçüncü durum olan "kötü yola düşme" ise karakterlerin hayatında yeni ve kötü bir sayfa açar ve bu felaketi yaşayan kadın kahramanlar dilencilik yapmak zorunda kalma, aileden ve sosyal çevreden kopuş, toplum tarafından aşağılanma gibi acıma doğuran diğer durumları yaşarlar. Tüm bunlar, Tanzimat romanında ve dolayısıyla bu romanların alımlayıcılarında duygudaşlık doğurur. Fakat bu durumların fenalığına veya mevcudiyetlerine dair ortak bir görüş bulmak zordur. Örneğin, Tanzimat romanının en gözde konularından olan "esaret”, Servet-i Fünun romanında âdeta çözülmüş problem gibi gözükür. Odalıklar ve cariyeler yine var olsalar da yoğunluklarını kaybetmişler ve bazıları mürebbiyeler ve kalfalarla yer değiştirmiştir. ${ }^{3}$ Yoksulluk ise Tanzimat romanında, katharsis'e yol açmayacak denli sıradan bir gerçeklik olarak sunulur. Bu durum, Ahmet Mithat romanında yoksulluğun olmadığı anlamına gelmez. Onun tüm ideal tipleri, yoksulluk derdini yok etmeye çalışsalar da sefalete düşmek yerine sermaye biriktirmeye uzanan macera içinde ilerlerler. Toplumsal gerçeklikten uzak olmakla suçlanan Halit Ziya romanlarında ise fakirliğin yol açtığı durumlar daha belirgin bir şekilde işlenir. Mai ve Siyah'ta Ahmet Cemil'in sınıfsal konumunun sebep olduğu durumların yanı sıra onun kenar mahallelere uğramak zorunda kaldığında gördükleri, Türk romanında acıma duygularını uyandıran sahnelerin başında gelir. Ferdi ve Şürekası'nda İsmail Tayfur'un ve babasının çalışma koşulları neredeyse sosyal gerçekçiliğe

\footnotetext{
${ }^{2}$ Ahmet Mithat, Dağarcık'ın yedinci sayısındaki "Fakr u Gına” yazısında, dünyada servetin eșit olması durumunda zaten kimsenin kimseye hizmet edemeyeceğini ve bu yüzden servet farklıllı̆ının doğal olduğunu savunan geleneksel görüșe iki noktadan itiraz eder. İlk önce "Ekonomi politik ilmiyle perverşeyab olan bu fikir şu itikade gülecek olsa tayin edilir mi?" diyerek bu fikri, her şeyden önce bir iktisatçı olarak gülünç bulur. Fakat asıl itiraz "eşitlik" fikri üzerinden yapılır: "Bir insanın hadd-i zatında ne salahiyeti olabilir ki diğerini kendisine hizmetkâr addedebilsin?” (s. 284). Bu anlamda, Ahmet Mithat, Dağarcık'taki "fazla Aydınlanmacı" bu yazılarından ötürü çıktığı sürgünün dönüşünde bu tür düşüncelerle meşgul olmamayi tercih eder.

${ }^{3}$ Selçuk Çıkla (2004), Servet-i Fünun romanlarında cariye, odalık vb. Servet-i Fünun romanlarında ne ölçüde görüldüklerini ayrıntılarıyla incelediği çalıșmasında şu tespitte bulunur: "Osmanlı İmparatorluğu'nda köleliliğin kalkıș yıllarına rastlayan Servet-i Fünun romanlarının çoğunda dadı, kalfa, halayık, ușak ve hizmetçi sıfatlarını taşıyan kişilere, az bir kısmında da köle mesabessindeki uşak ve halayıklar ile cariye ve müstefreșelere rastlanmaktadır." (s. 338). Halit Ziya'nın hikâye ve romanlarında esaretin görünümlerine dair önemli bir kaynak için bk. (Çağın, 2016).
} 
varan bir somutlukla anlatılır. Sefile'nin açılış cümleleri bile yoksulluğu Tanzimat romanında hiç olmadığı kadar görünür hale getirir. Kuşkusuz, acıma doğuran durumların kimi zaman göz ardı edilip kimi zaman vurgulanmasında, insan hallerine dair dünya görüşünün yanı sıra politik nedenlerin de bir etkisi bulunmaktadır.

\section{YOKSULLUK HALLERINE GENEL BİR BAKIŞ}

Kuşkusuz ekonomi bilimine ve toplumun iktisadi meselelerine oldukça meraklı olan Ahmet Mithat'ın "yoksulluk" ve "yokluk" kavramlarının -kendisince- felsefi sorgulamalara girişecek denli farkında olduğu muhakkaktır. Sürgün öncesi romanlarından olan Firkat'te (2001) yoksul bir insanın toplum tarafından küçümseme (istihfaf) ile karşılanacağını söyledikten asıl fakir olanların fakirliğin farkında olmayanlar olduğunu ifade eder.

"Evet, ama fakr insan için medar-1 istihfaf olamaz. Filan fakirdir diye tayip edilemez. Zira fakr u fakkanın keyfiyat ve derecatından haberi yok gibi görünenler daha ziyade fakirdir. Çünkü bir fakirin havayic-i zaruriyesi onlardan az olup onlar tadat ve tarife sığmayan havayic-i zaruriyeleri altında ezilip kalmıştır. Fakr, insan için medar-1 iftihar dahi olabilir. Zira fakr, insanlığa daha yakındır. Efkâr-1 felsefeye daha muvaffiktır" (s. 117).

Ne var ki sürgün sonrasında Ahmet Mithat'ın ilgisini fakirliğin fakirlik halleri değil orta sınıfın zenginleşme macerası daha çok çeker. Ahmet Mithat'ta yoksulluğun merhamet uyandıracak bir vaka olarak görülmesine dair ise belirgin bir görünüm mevcuttur: Yoksulluğun yol açtığı sefalet daha çok Avrupa'da geçen romanlarında görülür. Şüphesiz İstanbul'da da yoksulluk vardır, fakat Osmanlı vatandaşları sefalete uğramazlar ve Ahmet Mithat'ın ideal tiplerine verdiği reçeteye uydukları takdirde varsıllığa doğru ilerlerler. Bu noktada, Deniz T. Kılınçoğlu'nun (2017) Ahmet Mithat romanlarındaki iktisadi örüntüye dair tespitlerini hatırlamak yararlı olacaktır. Kılınçoğlu'na göre, Ahmet Mithat romanlarında baş karakterler hiçbir zaman toplumun dip tabakasından gelmez.

"Ahmed Midhat'nn Felatun Bey ile Rakım Efendi, "Bahtiyalık" ve "Para!" adlı roman ve öykülerinde bu temayı andıran örnekler varsa da, Ahmed Midhat'ın iktisadi başarı öyküleri "sıfırdan" yani aşırı yoksulluktan (rags - paçavralar) başlamaz. Onun öykülerindeki başarılı karakterler genelde "orta sınıf" diye tabir edebileceğimiz, çok zengin olmasa da çocuğunu iyi okullarda bir şekilde okutabilecek maddi durumu olan ailelerden gelirler" (s. 252).

Kılınçoğlu, bu tespitinden sonra aşırı yoksulluktan zenginliğe geçiş hikâyesi olarak Mehmed Tahir'in Netice-i Say'ini verir. Bu romanın baş karakteri olan kimsesiz çocuk dilencilik yapar fakat kazandığı bu parayı sermaye olarak kullanır. Devrin kanonu dışında kaldığı açık olan bu roman on dokuzuncu yüzyıl Türk romanında neredeyse bir istisna konumunda kalır. ${ }^{4}$ Acıma uyandıran yoksulluğa dair daha zengin malzeme, Hüseyin Rahmi'de, bir ara nesil şairi olarak ün kazanan Mehmed Celal'in romanlarında ve toplumdan kopuk olmakla suçlanan Halit Ziya'nın eserlerinde görülür. Ahmet Mithat çizgisinde ilerleyen Fatma Aliye de İstanbul'da yoksulluk ve sefaleti konu edinmese de ablası Emine Semiye için yokluk, yoksulluk, eşitsizlik temel bir problemdir. Yazarın 1896 ve 1898 yılları arasında tefrika edilen fakat 1924 'te kitap olarak basılan romanı Sefalet' in adı ve ara başlıkları bile bu sorunsalın yazar için ne denli öncelikli olduğunu gösterir: "Açlık, Sefalet İçinde İsmet - Nefret İçinde Muhabbet, Sada-yı Vicdanî, Sabite, Zaruret, Soğuk, Sabite'nin Âhı, Ulûvv-i Himmet, İnsan Şeklinde Bir Melek, İzdivaç, Hayati'nin Düğün Hediyesi, Vasiyet ve İstirahat-i Kalb".

Servet-i Fünun dergisinde yoksulluğun yansımasına dair yapılan bir araştırmada ${ }^{5}$ gezi yazısı, mektup, haber gibi kurgu dışı metinlerde yoksulluğun görünümünün baskılanmış olduğu, fakat öykü, şiir ve roman gibi türlerin bu sorun karşısında daha ifşa edici bir tavır takındıkları vurgulanır. Buna rağmen, sunum ve üslup farkından öteye geçen bir algılayış ikiliğinin de olduğu muhakkaktır. "Fakat

\footnotetext{
${ }^{4}$ Netice-i Say, ancak 2019 yllında Latin harflerine aktarllabilmiştir. Bk. (Mehmet Tahir, 2019)

5 115K608 nolu "Osmanlı Kültür Tarihinde Servet-i Fünun Dergisi" adlı TÜBíTAK projesi kapsamında hazırlananan bu yazı için bk. (Y. İ. Kaplan, 2018)
} 
kimisi fakirliği ve fakirleri aşırı duygulanım içerisinde anlatırken, ötekisi meseleyi modernliğin önlerine sunduğu bir arıza olarak görebilmekte, bir başkası da durumu iktisadî-sınıfsal katmanlaşmanın bir sonucu olarak algılamaktadır." (Y. İ. Kaplan, 2018) Bu anlamda, bir ara nesil yazarı olmasına rağmen Mehmet Celal'in romanları ilk gruba, Halit Ziya'nın özellikle Ferdi ve Şürekası romanı ikinci gruba örnek olarak gösterilebilir. İlkinde yoksulluk her ne kadar cemiyet-i beşeriyenin sebep olduğu bir durum olsa da duyguları tahrik için bir araçtır, ikincisinde ise yoksulluğun doğurduğu duygular, toplumsal boyutlarıyla nedensellik içinde verilir.

\section{AHMET MITHAT EFENDİ: YOKSULLUKTAN VARSILLIĞA}

Ahmet Mithat Efendi'de merhamet/acıma doğuran yoksulluğun görünümlerini incelemeden önce, Ahmet Mithat'ı şekillendiren kültürün varsıl-yoksul anlayışını ve Ahmet Mithat'ın bu anlayış karşısındaki tavrını incelemek gerekir. Ahmet Mithat, Dağarcık'ın yedinci sayısında yer alan "Fakr u Gına" yazısı bu bahis için oldukça yararlı malzemeler sunmaktadır. Ahmet Mithat, yazının başlangıcında zenginlik ve fakirlik arasında bir fark olmadığını söyleyen geleneksel görüşü şu şekilde özetler: Zengin ve fakir diye bir ayrım yoktur. İkisi de yaşamaya devam ettiğine göre gerekli olan gıdayı almaktadır ve bu durumda zenginlik ve fakirlik gibi bir ayrımdan bahsedilemez. Fakat Ahmet Mithat, bu görüşe itiraz eder ve fakirlik ve zenginlik arasındaki farkı dramatize ederek anlatmaktan çekinmez. Verdiği birçok örnek, iki grup insan arasındaki tezatı vurgulamak üzere kurgulanmıştır ve kısaca şu alıntının duygusal tonunu paylaşır: "Fakir vardır ki illet-i cev'aya takat gösteremeyen maddesini aldatmak için üzerine sımsıkı taş bağlar. Buna mukabil ganî, artık hazme-i takati kalmayan maddesine vüsat vermek için kuşağını gevşetir” (Sarıdoğan, 2014, s. 282). Ne var ki Ahmet Mithat'ın romanlarında bu türden "midesine taş bağlayan fakir" örneğine pek rastlanmaz. Oysa Ahmet Mithat'a göre romanın görevlerinden biri de okura dünya bilgisi vermek ve okuru hayatın tüm durumlarına dair bilgilendirmektir. Hatta Taaffüf'te (2018) anlattıklarını "sosyoloji denilen ve insanların usul-i maişetlerindeki kavaid ve hikmete müteallik olan dakik ve vasi bir ilmin mesail-i esasiyesi" (s. 26) olarak görür. Ona göre, eğlence için roman okuyanlar bu ilmin "mukayese ve muhakeme"sini yapmakla görevli değillerdir. Yine de, "[r]oman karileri ise okudukları şeylerden alabilecekleri ibreti almakta ve hatta almamakta dahi muhtar olarak, onlar yalnız kendi eğlencelerine bakarlar" (s. 26). Roman türünün "insanların daire-i medeniyet içinde hakikat-1 bahtiyarisi ile hakikat-1 bedbahtisini mertebe-i tahakkuka vardır[an]" sosyoloji ile eş tutulduğu açıktır. Hayret (2000) romanında ise yine bu konuyu oldukça ayrıntılı bir şekilde "anlatıcı sesi” ile ele alan Ahmet Mithat romanın görevini şöyle açıklar: "İnsanlara her hakayık ve hafayasıyla beraber hayatı göstermelidir ki o hayat âleminde işte böyle fenalar olduğunu dahi anlayarak terakkilerini medar olsun" (Ahmet Mithat, 2000a, s. 188). Romanın ilerleyen sayfalarında bu husus bir kez daha vurgulanır. "Roman okumaktan maksat, masal dinlemekten ziyade ahval-i cihana vukuf peyda eylemek"tir (s. 258). Dürdane Hanım'da ise sevgilisi Mergub Bey tarafindan türlü şekillerde kandırılan Dürdane Hanım'ın haline üzülen Ulviye Hanım, haline acıdığı kadının hiç roman okumadığını itiraf etmesi üzerine kendi kendisine şöyle der: "Eğer son romanları okumuş, hem de kemal-i dikkat ve itina ile okuyarak erkeklerin kadınların ahvalini layıkı veçhile öğrenmiş olsaydın kendini bu vartaya düçar etmezdin" ( 2017a, s. 139). Ne var ki Ahmet Mithat romanlarında hayatın bir tarafı, "daire-i medeniyet içindeki hakikat-i bedbahti”si hep eksik kalır. Sefalet, Ahmet Mithat romanlarına bakılacak olursa, Osmanlı topraklarında hiç görülmez, görülse bile gayrimüslimlerin başına gelir. ${ }^{6}$ Hatta Osmanlı'da fakirliği sergilemenin oryantalist bir tavır olduğunu bile söyler. Paris 'te Bir

\footnotetext{
${ }^{6}$ Ahmet Mithat'ta fakirlik gibi, fuhşun da coğrafyası vardır. Henüz On Yedi Yaşında (Ahmet Mithat, 2017c) romanında Rum Kalyopi'yi kötü yola düşüren yine Rumlardır. Nitekim roman boyunca Müslümanlar hep iyi niteliklerle, gayrimüslimler ise felaketlere yol açan eylemlerle ilişkilendirilmiştir. Öyle ki, geneleve gelen Türk müşteriler bile övülür. Sohbet sırasında Kalyopi, tercih ettikleri müşterileri "efendilerden beylerden" olduklarını söyleyince Ahmet Bey "Niçin mösyölerden dahi demiyorsun?” sorusunu yöneltir. Kalyopi, "yerli Hıristiyanlar"ı bile tercih etmediğini peşinen belirtip "Aman aman! Allah yine Türklere zeval vermesin. Bize
} 
Türk romanındaki karikatürize bir tip sayılabilecek İngiliz Mister James, karakalem bir resim yapar ve arkadaşı Fransız Autrans "Şu kıyafette gördügünüz resmin altına şu ibare yazılacak: 'Şarkta bir fakir. Ressam-1 meşhur İngiliz Mister James tarafından resmolunmuştur.” James, bu alt yazıyı coşkuyla onaylasa da Nasuh, "İyi! Lakin böyle fakir olmaz!” (Ahmet Mithat, 2017b, s. 36) diyerek itiraz eder. Aldığı cevap, zaten kendisi de karikatürize bir tip olan İngiliz Mister James’in görmediği bir fakirliği mübalağa ederek karikatürize bir şekilde resmettiğini itiraf etmesiyle sonlanır. Ahmet Mithat'ta fakirlik, Batılı karakterlerin maruz kaldığı durumlardır veya yoksulluğa dair gündelik tespitler hep Avrupa'ya mahsustur.

Orhan Okay, Ahmet Metin ve Şirzad'daki “Avrupa ahalisinin yüzde sekseni o kadar fakirdir ki bu fakr u zaruretin netayici ilcaatından hükema bihakkın endişe ediyorlar.” (Ahmed Midhat, 2011, s. 496) cümlesini de alıntılayarak Osmanlı'da sınıfsal bir toplum yapısının olmamasından dolayı Ahmet Mithat'ın Osmanlı ve Batı farkını bu karşılaştırma üzerine kurduğuna değinir. Ona göre, Ahmet Mithat, Avrupa'da Bir Cevelan'da Avrupalıların evlerinin olmayışı karşında İstanbul halkının yüzde seksenin kendi evlerinde oturduklarını belirtir (Okay, 2017, s. 196). Romanlarda ise Avrupa'da sefaletin örneklerini bulmak zor değildir. Diplomalı Kız'da Julie'nin anne ve babasının ne tür yokluklar çektikleri okurda güçlü bir acıma uyandıracak şekilde verilir. Oysa Ahmet Mithat'ın ideal tiplerinden sayılabilecek Resmî Efendi de görece zor koşullardan gelmiştir. Babası ölmüş, babasından kalan parayı ise ağabeyi içki illetine dalarak tüketmiş, hatta sonunda delirerek ölmüştür. ${ }^{7}$ Böylece Resmî ve annesi, "fakr u zaruret içinde" kalır. Fakat bu yokluğa rağmen, annesi "büyücek bir haneyi”" satıp parasını aylara taksim eder ve her ay bir kısmını harcayarak Resmî'nin para kazanacağı zamanlara ulaşırlar. Ahmet Mithat'ın İstanbul'da "fakr u zaruret"ten anladığı işte bu türden bir yoksulluktur. Felatun Bey ve Rakım Efendi (2000b) romanında, henüz bir yaşındayken babası, oğlu Râkım'a ve eşine Salıpazarı civarında üç odalı çürük bir ev ve bir Arap cariye bırakmıştır. Ev çürük olsa da nihayetinde üç kişiyi rahatça barındırır ve Fadayi isimli Arap cariye, evin geçimi için büyük çaba harcar. Ahmet Mithat'1n Osmanlı'ya özgü sosyal dayanışma örgütlenmesine bir örnek teşkil eden bu durumun da sayesinde Râkım Efendi, Hariciye Kalemi'ne girmesine olanak sağlayacak bir eğitim alır. Dolayısıyla, Ahmet Mithat Efendi'nin romanlarında yoksulluk, acıma duygusu uyandıracak denli güçlü bir sosyal durum olmaktan uzak bir görünüm sergilemektedir. Bu bakımından, Şerif Mardin'in Ahmet Mithat'ın eserlerinde, "[içinden] çıktığı küçük esnaf çevresinin etkisiyle ‘küçük adam'ın dertlerini ortaya döken bir tarafı” (Mardin, 1990, s. 74) olduğu fikri de tartışmaya açık olduğu söylenebilir. Ahmet Mithat'ın eserleri, ansiklopedik bilgi bakımından onca zenginliğine rağmen şehir hayatının kenar mahallerine dair manzaralar ve bilgiler bakımından oldukça yetersizdir. Örneğin Hüseyin Rahmi'de bir bakkal dükkânın tasvirine yakın bir tasviri Ahmet Mithat romanında bulmak oldukça güçtür: "Bakkal, tavandan hevenk hevenk sarkan hasır çalı süpürgeleri, varakları sinek tersiyle kararmış güllaçlar, sucuklar, çamaşır ipi turaları, tahta firçaları, o mahallece vüs'at-i sermayesine delalet eden bu muallakat-i ticariyesi altına oturmuş yağlı bir tahta masa üzerine mevzu defter-i kebirini karıştırıyor[...]" (Gürpınar, 2015, s. 178). Aynı şekilde, Ifffet (2018) romanında İffet'in evine ulaşmak için "hâl-i hayatlarında mükemmel bir iskelet dersi göstermeye yarayacak kadar zayıf ve dermande olan" (s. 50) hayvanların çektiği köhne arabalarla gidilen kenar semtleri de Hâce-i Evvel'in romanlarında bulmak zordur. İffet' in annesini tedavi etmeye giden doktorun ve arkadaşının bu yolculukları, aynı zamanda İstanbul'da fakirliğin canlı anlatımlarını da verir. "Köşesinde camları sararmış harap bir kahve bulunan” sokaklardan sapıp "çirkefler akıtılmış ve kümes

en güzel muamele eden yine Türklerdir." (s. 133) cevabını verir. Kalyopi'nin bu yola düşmesine neden olan başlıca etken onun ailesi ve Rum toplumudur. Halit Ziya'nın Sefile'si bu politik tutumu tersine çevirir. "Açıkçası bu roman [Sefile], romantik özellikler tașıyan Henüz On Yedi Yaşında romanının bir antitezi ve dolayısıyla Ahmet Mithat'ın roman anlayışına verilmiş bir cevaptır" (Huyugüzel, 2015, s. 11)

${ }^{7}$ Resmî Efendi'nin ağabeyinin, babasından kalan serveti bu șekilde tüketmesi, Ahmet Mithat'ın "defolu ideal tip" olarak tanımlayabileceğimiz kahramanlarından Resmî”nin daha sonra Madam Hamparson'a tutularak ideal çizgiden uzaklaşmasında bu tür bir genetik yatkınlık altyapısı oluşturmak istemesi ile de açıklanabilir. 
kadar küçük, harap hanelerin önünde murdar entarili [birtakım etfal]"in önünden geçerler. "Bazı evlerin önünden geçerken hissolunan mayıs kokusu ve arada bir işitilen inek sedaları insana kendinin İstanbul'dan uzak bir köyde bulunduğunu" düşündürür. Bir yerden sonra ise İstanbul'un sokaklarını dolduran köpeklerden bile eser kalmaz. "İnsanların doyunca [doyacak kadar] ekmek bulamadıkları bu sokaklardan onlar da çekilmişlerdi[r]. (Gürpınar, 2018, 57-58). Tüm bu sefalet sahnelerinden sonra ulaştıkları evde ise İffet'in annesi, gördüğ̈̈ yardım karşısında doktora ve arkadaşına şöyle der: "Her ikinizin tenezzülen teşrifinize teşekkür ederim. Fukaraya acıyanları Cenabıhak mükâfatsız bırakmaz. Sizi bana gönderen Allah elbette sizi maksudunuza eriştirir” (s. 64). Görüldüğü gibi, İffet'in annesi acıma duygusunu dinî bir referansla kullanıp onu "merhamet"e dönüştürür. Fakat bu dil, tıpk1 Sergüzeşt’te olduğu gibi ikincil önemdeki karakterlere özgüdür. Anlatıcı veya anlatıcı rolünü üstlenen karakterlerin acıma uyandıran durumlar karşısında farkı bir tavır takındıkları görünür. İffet'in annesi tarafından fukaraya acıdığı için dua edilen anlatıcı, gördüğü yoksulluk manzaraları karşısında Tanrı'ya sığınmak veya ondan yardım istemek yerine bedddua eder. "Rızkı verenin Allah olduğu” veya Allah'ın muhtaçları ödüllendireceğine vb. yönelik bir dini söylem yerine Tevfik Fikret'in "Ey her açılan rahnesi bir vak'a sayıklar / Viraneler, ey mekmen-i pür-hâb-1 eşirrâ" isyanını andıran bir sitemle İstanbul'a seslenir:

"İstanbul... Ey koca şehr-i İstanbul! Şu dört makhur talihi nerende saklıyorsun? Amîk, muzlim kuyularında mı? Harap, garibane mezarlarında mı? Yoksa bî-vayegâna meva olan virane kulübelerinde mi? Yüz binlerce nüfusa mesken olan la-yuad hanelerinden bu mazlumlar için bir odacık bulunamadı mı? Gümrükler, hanlar, mağazalar, dükkânlar almayan bunca ithalat zahairinden bu dört açın nafakası neden istisna ediliyor?" (Gürpınar, 2018, s. 115).

Ahmet Mithat için ise sokak, ancak gündelik hayatın kurguya renk katacak bir ögesidir. Orada yaşanan acılar görmezden gelinir. Tanpınar, Ahmet Mithat'ın kurgusunun türlü helva sohbetinin tarifi, Edirne'de geçen bir vakanın hikâyesi, buradan hareketle şer'i mahkeme kayıtlarının önemi, Balat'taki içki fasıının mukaddimesi, Yahudilerin zevkleri ve yaşam tarzları, bu vesileyle Yahudi kayıkçının anlattı̆g fikra vb. şeklinde anekdotlar, fikralar ve malumatlarla ilerleyen çizgisinden bahsettikten sonra, onun okur kitlesiyle arasındaki anlaşmayı şöyle açıklar: “ $\mathrm{O}$, bu kadar biçare şekilde canı sıkılan insanlara, daha doğrusu her ağzını açışta meselelerini yutmaya alışmış bu can sıkıntısının kendisine hitap ediyordu. Çünkü esnaf kahvesinde konuşma can alacak hiçbir noktaya basmayacaktır. Istırap, sefalet, insan talihinin acı tarafları 'saye-i şahenede' çoktan halledilmiştir' (Tanpınar, 2008, s. 416). Hace-i Evvel, türlü sosyal meseleler etrafinda gelişen romanlarında İstanbul'un yoksulluğuna değinmemiş, bu konuyu Hüseyin Rahmi'ye, ara nesil olarak tasnif edilen Mehmet Celal gibi yazarlara ve toplumdan uzak olmakla suçlanan Halit Ziya gibi Servet-i Fünun yazarlarına bırakmıştır. Diğer yandan, şehir mektupçusu Ahmet Rasim'in romanlarında toplum hayatından sunulan izlerin, gazete yazılarının aksine, çok da güçlü olmadığı görülür. Elbette, Ahmet Rasim'in romanlarında sosyo-ekonomik yansımalar ayrı bir çalışmayı hak etmektedir. Bununla birlikte, Ahmet Rasim romanlarında zorluk, hayat endişesi veya sefalet kavramlarının bağlamları Halit Ziya'nın "hakikiyyun” anlayışı ile uyuşmamaktadır. Ahmet Rasim'in Meşakk-ı Hayat başlıklı romanında "hayatın zorlukları”ndan kastı, kocasının çiçek bozuğu yüzüne tahammül edemeyen kadının evi terk ettikten sonra yaşadığı zorluklardır. Mehalik-i Hayat’ta "hayatın tehlikeli yerleri/işleri" ile ifade etmeye çalıştı̆̆ 1 gerçek, bir zamanlar "hayat-1 sefilane"ye

\footnotetext{
${ }^{8}$ Ekrem Işın'ın on dokuzuncu yüzyıl İstanbul sokaklarında köpekler üzerinden yaptığı tespitler ("Dört Ayaklı Belediye ya da İstanbul Köpekleri") göz önüne alındığında "köpeklerin bile olmadığı İstanbul sokakları"nın "merhamet”ten ne denli soyutlandığı daha görünür hale gelir. Köpekler, "[...] Müslüman dünyasında kurumlaşmış merhamet duygusu tarafından güvence altına alınmıştı. Her ne kadar ulema sınıfı, köpeği, mekruh bir hayvan saymış ve evde beslenmesini şiddetle yasaklamıșsa da dinsel inancın sokağa çıkmıș biçimi olan hurafe kültürü, merhamet duygusunun kapsamını yasak sınırının ötesine doğru genişletebilmişti." Yabancı gezginlerin hayretle kaydettikleri köpeklere gösterilen yakın ilgi, bu kurumlaşmış duygunun koruyucu kanatları altında gelişerek, mahalle aralarında küçük barınakların ve çeşmeden su içebilmeleri için özel yalakların yapılmasına yol açtı.” Bk. (Işın, 2014, s. 221).
} 
bulaşmış bir kadının ve kıskançlık krizine tutulmuş kocasının, başka bir kadının fesadına uğramasıdır. Endişe-i Hayat'taki endişe, karısını kıskanıp bir adamı öldüren adamın karısından mektup alamayan adamın, kocası hapishanedeyken "hamisiz kalan bir kadının mutlaka sefil olacağını"n (Ahmet Rasim, 2019, s. 314) somut bir örneğini teşkil eden bir kadının ve o kadına hamilik eden gencin endişeleridir. Dilenci karakterler bile İstanbul'da yaşamanın ekonomik olarak ne kadar zor olduğu fikrine değil, kaderin bir cilvesine işaret eden didaktik ve ahkaki bir fikre hizmet eder. Bu romanlarda toplumda özellikle kadınların yaşadıkları zorlukların sıkça vurgulandığı ve bir cezaya müstahak karakterlerin sefaletleri anlatılsa da, sıradan insanın geçim derdine veya yoksulluk problemine güçlü bir şekilde değinilmediği görülür.

\section{SERVET-İ FÜNUN: YOKSULLUKTAN SEFALETE}

Agâh Sırrı, Edebiyat Tarihi Dersleri'nde (1938) Halit Ziya'nın hikâyelerini küçük birer romana benzeterek şu yargıda bulunur: "Bu hikâyeler, keskin bir zekânın hemen bir adese kudretiyle yakalayıp çok defa merhametsizce tespit ettiği reel vakaları değil, belki insanda acıma hissini uyandıran hazin mevzuları taşır." (aktaran Aslan, 2019, s. 24). Gerçekten de, Halit Ziya'nın hikâyeleri, Aslan'ın da belirttiği üzere'; yoksul, sakat, umutsuz ve çaresiz insanları konu edinir. Yaşlı bir kadın çocuğunun ihtiyacı olan ilacı almak için eczaneye gider, fakat elindeki tek para olan kâğıt banknot yırtıktır ("Bir Hazin Hatıra"). Hikâye, bu yokluk ve insanın bu yokluk karşısındaki ezilmişliği üzerine kuruludur. Ahmet Mithat'ın hiçbir zaman bu denli dramatize etmeyeceği türden kurguları barındıran hikâyelerin yanı sıra, Halit Ziya'nın romanları da acıma ve merhamet hisleri bakımından zengin bir içeriğe sahiptir. Diğer taraftan, Halit Ziya'nın sosyal hayata verdiği önemi Mehmet Rauf'ta bulmak güçtür. Rahim Tarım (2000), Mehmet Rauf'un kaleme aldığı hikâyelerin 143 hikâyenin konularına göre tasnifini yaparken sadece "Buhran", "Ayşe Kadın", "Girdap" hikâyelerinin bu konuyu işlediğini belirtir (s. 136). Bu çalışmada ise, bu iki yazarın on dokuzuncu yüzyılda yayımladıkları romanlarına odaklanılacak ve acıma duygusu uyandıran yoksulluğun kapsamları, bu duygunun ne ölçüde merhamete dönüştüğü ve epistemolojik niteliği üzerinde durulmaya çalışılacaktır.

Halit Ziya'nın ilk romanı Sefile ${ }^{10}$ şu cümlelerle açılır: "Düşündü, tereddüt etti... Mahzunane gözlerini indirerek zayıf vücudunu nim setr eden paçavraları, çamurlar içinde mülevves olan ayaklarını süzdü” (2015, s. 15). Bu cümlelerin öznesi sokaklarda dilencilik etmek zorunda kalan Mazlume'dir. Henüz bir yaşında babasını kaybeden Mazlume'nin hatırlayabildiği parçalı hatıralarından her biri, bir sefalet dekorunun başka bir parçasını oluşturur: Evleri küçük ve basıktır, öyle ki yağmurlu havalarda odaları karanlığa bürünür. Dahası, annesi hastadır. Mazlume, annesinin derin iniltileri ve ac1 feryatlarıyla büyür ve sonunda bir gece annesinin ölümüne de şahit olur. Yine de Mazlume, tümüyle yalnız değildir. "Merhameti ifrat derecesinde bir kadıncağız olan" (s. 28) ve bu özelliği isim sembolizasyonuyla da vurgulanan Rahime Hanım, Mazlume'yi evine alır ve onu en azından ekonomik zorluktan uzak tutar. Bu açıdan, sefalet karşısında "merhamet” in hiç vakit kaybetmeden devreye girdiği görülür. Fakat bu küçük ölçekli merhametin süresi de kısadır. Mazlume on iki on üç yaşına geldiğinde Rahime Hanım ölür. Anlatıcı bu ölümü şu cümleyle açıklar: "Lakin kader, Rahime Hanım gibi biçare kıza validesizliğini, pedersizliğini unutturacak derecelerde ibzal-i şefkat eden bir hamiyi de çok gördü” (s. 29). Böylece, Mazlume'yi başka bir kötülükle karşı karşıya bırakan gücün kader olduğu vurgulanır. Mazlume'nin yaşadığı zorluklarda hiçbir hatası yahut payı yoktur ve onu bu hale sokan güç “doğaüstü”dür. Bu anlamda Mazlume, merhameti sonuna kadar hak eder. Fakat toplum da kaderle iş

\footnotetext{
9 “Halit Ziya'nın hikâyelerinde merhamet duygusu da üzerinde en çok durulan tema ve konulardan birisidir. Hikâyelerinde merhamete konu olan kişiler genellikle zayıflar ve çocuklardır. Bu hikâyelerinde yoksul, sakat, umutsuz, çaresiz insanları anlatır." (Aslan, 2019, s. 276).

10 "Nemide, Halid Ziya Uşaklıgil'in tefrika halinde kalan Sefile'sinden sonra yazdığı ikinci romanı olmasına karşılık, kitap olarak basılan ilk romanıdır” (Sağıroğlu, 2005, s. 5).
} 
birliği içindedir. O güne dek yalnız yaşayan Rahime Hanım'ın mirasçıları birdenbire ortaya çıkarlar ve Mazlume evsiz kalır. "Müracaat edecek hiçbir ev, merhametinden emin olacak hiçbir kimse tanımıyordu” (s. 30). Böylece Ahmet Mithat’ta hiçbir zaman göremediğimiz, yersiz yurtsuz kalan kız çocuğunu Halit Ziya'nın ilk romanında ortaya çıkıverir. Sosyal dayanışma, sadece kısa süreli ve güçsüz tek bir halka olarak belirebilmiş, kötülükler kader tarafından yağdırılmış ve insanlar on üç yaşındaki bir çocuğun sokaklara atılmasına sebep olmuştur. Mazlume için "merhametinden emin olabileceği” tek bir insan bile yoktur. Çaresizlikle bir komşusunun kapısını çalan Mazlume, burada ancak on beş gün misafir kalır ve hiçbir komşu onu evine almak istemez. Böylece sosyal dayanışmanın hiç var olmadığı bir toplum portresi çizilir. On beşinci geceyi Beyazıt Camisi'nin avlusunda geçirmek zorunda kalan Mazlume'nin başına gelenleri hak etmeyişi, birilerinin ona acıma/merhamet duymasına ne denli muhtaç olduğu ve toplumdan dişlanmışlığı birkaç kez vurgulanır. "On üç yaşındaki bir çocuğa pedersizlik, validesizlik gibi azim bir bedbahtlık kâfi değil mi ki Mazlume'yi himaye edecek bir sahib-i merhamet bulunmuyor" (s. 31). Cami avlusuda uzun bir gece geçiren Mazlume'ye hiçbir el uzanmamıştır. Hatta Mazlume, on gün boyunca cami avlusunda bir hasırın üzerinde yatmış olmasına rağmen "müşfik, merhametli bir çehre" görememiştir. Ahmet Mithat'ın, merhameti dinî literatüre dayandırdı̆̆ 1 ender sahnelerden biri olsa da, Dürdane Hanım romanında, Sohbet Bey'in neden camide olduğunu açıladığı sözleri hatırlatmak yerinde olacaktır. Yaşam tarzı itibariyle camide olduğuna şaşırılan Sohbet Bey, "Orası Cenab-1 Allah'ın merhamet hanesidir. O haneye merhamete en ziyade ihtiyacı olanlar başvurur ve vurmalıdır" (Ahmet Mithat, 2017a, s. 146) der. Ne var ki bu durum Sefile'de geçerli değerlidir. Sefile'de anlatıcı, Mazlume'ye sadece bir kez yardım edildiğini bildirir: Mazlume ne yapacağını bilemez bir halde, caminin dışına çıkıp Mercan Yokuşu'nda bir firının önünde açlık çekerken eline ekmek almaya yetecek kadar para tutuşturulur. Ona uzanan ikinci el ise Mihriban Hanım'ın eli olur, fakat bu el onu yoksulluktan sefalete götürecektir. "Mazlume'nin sabır ve metaneti son dereceye varmıştı ki Mihriban Hanım'a müsadif oldu. Hanım ettiği teklif kızacağız tarafından pek mütehalikane, pek mesrurane kabul olunmalıydı. Fakat Mazlume sefaletten müthiş bir felaketin kendisine muntazır olduğunu cezmediyordu." (s. 33) Bu nedenle, Halit Ziya'da acıma duyulan karakterlerin maceraları, Ahmet Mithat'ta olduğu gibi hafif bir yoksulluktan refaha doğru değil, sert şartlardan daha sert şartlara, başka bir ifadeyle yoksulluktan sefalete doğru bir ilerler.

Bu ilerleyişte dikkati çeken bir diğer husus, "merhamet" uyandıran durumların "acıma" ile karşılanmasıdır. Aristo'nun acıma uyandıran üç şartından en az ikisini sağlayan karakterler (kötülüğü hak etmeme, kötülügün ciddiyeti, başkalarının da başına gelebileceği) hiçbir dinî referansla yardım görmezler. Her ne kadar anlatıcı "bir merhamet eli” için çağrıda bulunsa da, bu çağrı karşılıksız kalır. Mazlume, cami avlusunda on gün on gece geçirmesine rağmen, onun haline aciyan bulunmaz. Ekmek parası caminin dışında verilir ve onu kötü yola sürükleyecek olan Mihriban Hanım, onu caminin önünden alır. Bu durum, Mazlume'nin, müşkül durumdaki bir çocuğa Allah rızası için iyilik yapılmayan bir toplumda yaşadığ izlenimini uyandırır. Mazlume, ona merhamet edildiği duygusunu yaşamaya firsat bulamadan, onu felaketlere daha da çekecek olan İkbal Hanım'a merhamet duyar. "Genç kız anlayamıordu, fakat İkbal Hanım'a kalbinde bir eser-i merhamet hissediyordu" (s. 35). Böylece, Mehmet Celal'de de görülen- "cemiyet-i beşeriye"nin insanı felaketten kurtaran değil, felakete sürükleyen niteliğinin yansıması Halit Ziya'nın henüz ilk romanında görülür. Kuşkusuz, Halit Ziya'nın, romanını daha "acıklı" hale getirmeyi tercih ettiği ve bu nedenle kurguyu dramatize etmek adına acıma duygusunu dinden uzak tutmak için özel bir çaba sarf ettiği de düşünülebilir. Fakat bu iddiaya karşılık olarak öncelikle, Halit Ziya'nın Sefile'nin yayıma “şe'rait-i İslamiyeye mugayir"liğinden dolayı uygun bulunmamasına dair söylediklerine dikkat etmek gerekir.

"Şerait-i İslamiyeye mugayir görünen, romanın başlıca kahramanı Mazlume ismindeki Türk kızının fuhşun çamurlarına düşmüş olmasıydı. Encümen azası mezarlarından başlarını kaldırıp da bugünün haline bir baksınlar. Hatta o gün İstanbul'un bütün tenha sokakları o zavallılarla dolu idi” (aktaran Sağıroğlu, 2005, s. 11). 
Halit Ziya'nın, bu çalışmanın süre kapsamı içine giren romanları arasında, yoksulluğun bir acıma kaynağı olarak en belirgin görüldüğü ikinci romanı Ferdi ve Şürekası'dır. Bu roman, çalışan haklarına dair önemli veriler barındırması yanında, sınıf çatışmasını ve yaşamda kalma mücadelesini merkeze alan bir yapıdadır. Roman, başkarakteri İsmail Tayfur'un babası Abdulgafur'un -arkadaşı Hasan Tahsin'in anlatılan- hikâyesiyle açılır. Hasan Tahsin, "ismini ne vakit ansam kalbimde bir damarın sızladığını hissederim” dediği Abdulgafur’un, bir başkasının sermayesinin artması uğrunda harcadığı ömrüne acımaktadır. "Abdulgafur, benden on iki gün evvel alınmıştı... Ona da dört lira veriyorlardı.” (Ziya, 2006., s. 20) Zamanla işverenin sermayesi gerçekten de çoğalır, fakat Abdulgafur hiçbir sosyal haktan yararlanamadan hayatını kaybeder. "[B]u servet, bir ejder-i müthiş gibi şiştikçe şişti. Biz kurudukça kuruduk, bir gün Abdulgafur, ciğerlerinin kanını defterinin üzerine kusarak hayatını sarf ettiği rakamların içine ruhunu da boğup gitti” (s. 21). Görüldüğü gibi, yoksulluk çeken bir karakterin, çalışarak bu yoksulluktan kurtulma gibi bir şansı yoktur. Dahası, oğlu İsmail Tayfur da onunla aynı kaderi paylaşacaktır. Babası ölünce, onu okutma imkânından yoksun bir toplumda yaşayan genç olarak, babasının izini takip etmek zorunda kalır. Babasının eski iş yerine gittiği zaman kapıda duraklar, fakat Hasan Tahsin Efendi, "otuz senelik arkadaşının yetimini gördüğü vakit kalbinin en saf, en ulvi bir noktasaindan kopan bir hiss-i azim-i merhametle onun elinden tut[ar]" ve Ferdi Efendi'ye, babasının hak ettiği ödülü, oğulunu işe alarak vermesi gerektiğini söyler. Bu ödül, oğlunun da babası gibi, merhamet uyandıran bir yaşam sürmesine sebep olacak koşullardır.

Mai ve Siyah romanı ise (Uşaklıgil, 2015b) Ahmet Cemil ve Hüseyin Nazmi arasındaki sınıf/ekonomik güç farkı merkezinde gelişen olayların periferisinde yine kenar mahallelere uğrar. Babasının ölümüyle annesinin ve kız kardeşinin sorumlulukları omuzlarına binen Ahmet Cemil'in 1zdırabı ve çalışma gayreti Ahmet Mithat'taki Resmî Bey'in ve Rakım Efendi'ninkilerden çok daha sahicidir. Ahmet Cemil, "Duyduğu nefretle beraber ona acımaktan nefsini alıkoymadığı" meslektaşı Raci'ye kinini unutup ona yardım eder. Raci'nin hastaneye yatırılması sırasında hastane manzaraları, İstanbul'un "beşer hayatının mücessem bir sefalet muhassalası" olan fakir mahallelerinden geçişi sırasında gördükleri ve Raci'nin karısının sefaleti, kaçmak istediği gerçekliğin acı görünüşleridir. Ahmet Cemil, böyle anlarda hasetinden dolayı utancını hisseder ve anlatıcı bu ruh halini şu sözlerle aktarır: "Bir el çelikten tırnaklarıyla kalbini sıkıyor, bir ses: 'Bak bir de bu hayata; bu sefalet sahnesine bak' diyordu" (s. 354).

\section{SONUÇ}

Roman türü ile birlikte Türk edebiyatının sokağa indiği, romanın toplumsal meselelerle ilgilendiği ve hatta onu yönlendirmeye çalışan bir mecra olduğu açıktır. Ne var ki yoksulluk -özellikle Ahmet Mithat'ta- başlı başına yazmaya değer bir konu olarak görülmemiş ve bir başka konuya açılmak için bir vasıta olmaktan öteye gidememiştir. Ahmet Mithat'ta asıl ilgi çekici olan, girişimcilik faaliyetleriyle Müslüman-Türk bir burjuva sınıfının oluşmasıdır. Bu açıdan yoksulluk acıma uyandıran bir konu olmaktan uzaklaşmış ve bu özelliğini ancak Hüseyin Rahmi ile ve -daha belirgin bir şekildeHalit Ziya ile kazanmıştır. Bu anlamda, roman türünün imkânları sayesinde sokağa inen Tanzimat romanının sosyo-ekonomik koşullara dair bir acıma duygusu beslediğine dair örneklerin azlığı dikkat çekicidir. Toplumsal meselelerden uzak olarak kabul edilmesine rağmen Halit Ziya'nın daha ilk romanlarından itibaren parasızlık ve kimsesizlik nedeniyle "kötü yol"a düşen karakterlere rastlanır. Özellikle Sefile, yoksullukla birlikte toplumsal dayanışmanın olmadığı bir "cemiyet-i beşeriye" içinde yaşamak zorunda kalan bir genç kızın düştüğü durumları realist sayılabilecek tablolarla okura sunar. Bu iki örnek, acıma duygusu perspektifinden bakıldığında Ahmet Mithat ve Halit Ziya arasındaki politik tavır farkını da somutlaştırır. Ahmet Mithat'ın acıma uyandıran yoksulluğu -tam da herhangi iktidarın isteyeceği şekilde- topluma açmama veya onu görünür kılmama çabasına karşılık, Halit Ziya toplumsal bir sorunu eserlerine realist bir tavırla taşımışıtır. Tüm bunlardan sonra edebî eserde "acıma"nın estetik bir duygu halinden fazlası olduğu ve hele hele yoksulluk bağlamında politik bir veçheye de sahip olduğu 
sonucu çıkmaktadır.

$\mathrm{Bu}$ çalışmanın ilgilendiği diğer bir sonuç yoksulluk karşısında uyanan duygunun merhamet mi yoksa acıma olarak mı adlandırılması gerektiğine yönelik bulgular temelinde yükselir. Merhamet duygusu kaynağını dinî referanslardan alır ve bu duygunun bir eylemle tamamlanması gerekir. Diğer yandan acıma duygusu, bu duygunun daha seküler ve hümanist saiklere sahip hali olarak tanımlanabilir. Bu bakımdan, bu çalışmada ayrıntılı bir şekilde gösterilmeye çalışıldığı üzere, Batı literatüründe de acıma ve merhamet duygularının tarihsel izlerini sürebilmek mümkündür. On dokuzuncu yüzyıl Türk romanı odağında ise, Tanpınar'ın Mihnetkeşan'ındaki acıma duygusunu “Acıma hissi, kökünü dinden alan bir ahlakın ötesine geçer” (s. 266) şeklinde tanımlaması ve Kaplan'ın acıma hissinin Batı'dan ithal edildiğine dair tespitlerini bu bilgilerin ışığında okumak gerekir. İslam epistemolojinde önemli bir yeri olan merhametin varlığını inkâr etmeksizin Batı'dan ithal edilen bir tür olan romanda, bu nedenle, bir duygunun ithal edildiğini, bu iki duygu arasındaki varoluşsal farkı gözeterek yerli yerine koymak büyük önem taşımaktadır. Türk romanının ilk durumlarında "Allah rızası" gözetilerek uyanan bir acıma duygusundan daha ziyade, kaynağını Aydınlanma değerlerinden alan bir duygunun uyandığı görülür. Özellikle Halit Ziya'nın Sefile romanında Mazlume'nin cami avlusunda günlerce aç kalması, ona uzanan tek yardımın caminin dışındayken gelmesi ve Mazlume'nin kötü yola düşmesi, Mazlume'ye karş1 alımlayıcı düzeyde uyanan duygunun merhametten daha çok acıma olarak nitelendirilmesi gerektiği sonucunu doğurur. Elbette on dokuzuncu yüzyıl Türk romanında yoksulluk sahneleri bu çalışmada adları anılan başka romanlarla zenginleştirilebilir. Ne var ki bu sahnelerin acıma veya merhamet başlıklarından hangisi altına yerleştirilmesine dair bir şablonun oluşması, bu çalışmanın en önemli sonuçlarından birisidir. Yoksulluğun uyandırdığı duyguya dair yapılacak bu türden bir tasnif, sadece romanların anlaşılması için değil, on dokuzuncu yüzyıl roman yazarlarının yenilik ve gelenek arasındaki ikilemlerinin somutlaştırılması, bir duyguya dair saiklerinin değişip değişmediğinin izlenmesi için de yararlı bir enstrüman olacaktır.

\section{KAYNAKLAR}

Ahmed Midhat. (2011). Ahmet Metin ve Şirzad. (S. Ayhan ve L. A. Çanakl1, Haz.). Bursa: Dörtrenk.

Ahmed, S. (2015). Duyguların Kültürel Politikası. (S. Komut, Çev.). İstanbul: Sel.

Ahmet Mithat. (2000a). Hayret/Bahtiyarlı. (N. Sağlam, Haz.). Ankara: TDK.

Ahmet Mithat. (2000b). Felatun Bey ile Rakım Efendi. (K. Yetiş, F. Andı ve N. Birinci, Haz.). Ankara: TDK.

Ahmet Mithat. (2001). Firkat. F. Gökçek (Haz.), Letâif-i Rivâyat içinde . İstanbul: Çağrı.

Ahmet Mithat. (2017a). Dürdane Hanım. (M. F. And1, Haz.). Ankara.

Ahmet Mithat. (2017b). Paris'te Bir Türk. (E. Ülgen, Haz.). Ankara: TDK.

Ahmet Mithat. (2017c). Henüz 17 Yaşında. (N. Sağlam, Haz.). Ankara: TDK.

Ahmet Rasim. (2019). Endişe-i Hayat. Ö. İldeş (Haz.), Hikâye ve Romanlart-II içinde . Ankara: Kurgan.

Ardıç, B. (2002). Hadislerde Merhamet Kavramı. Uludağ Üniversitesi, Sosyal Bilimler Enstitüsü, Temel İslam Bilimleri Anabilim Dalı.

Arendt, H. (2017). Devrim Üzerine. (O. E. Kara, Çev.). İstanbul: İletişim.

Aristoteles. (2000). Retorik. (M. H. Doğan, Çev.). İstanbul: YKY.

Aslan, H. (2019). Halit Ziya Hikâyesine Tematik Bir Baklş. İstanbul: Kurgan.

Çağın, Ş. (2016). Halit Ziya Uşaklıgil'in Eserlerinde Esaret. Yeni Türk Edebiyatı, (14), 25-42.

Çağrıc1, M. (2004). Merhamet. Islam Ansiklopedisi. TDV.

https://islamansiklopedisi.org.tr/merhamet adresinden erişildi.

Çıkla, S. (2004). Kültür Değişmeleri ve Servet-i Fünun. Ankara: Akçağ. 
Fındıkoğlu, Z. F. (1999). Tanzimat'ta İçtimai Hayat. Tanzimat içinde (ss. 619-659). Ankara: MEB.

Gürpınar, H. R. (2015). Tesadüf. (C. Yalvarı, Haz.). İstanbul: Papersense.

Gürpınar, H. R. (2018). Iffet. (E. Tombul, Haz.). İstanbul: Dergâh.

Huyugüzel, Ö. F. (2015). Sefile Romanına Dair. Ö. F. Huyugüzel (Haz.), Sefile içinde . İstanbul: Özgür.

Işın, E. (1985). Osmanlı Modernleşmesi ve Pozitivizm. Tanzimat'tan Cumhuriyet'e Türkiye Ansiklopedisi. İletişim.

Işın, E. (2014). Dört Ayaklı Belediye ya da İstanbul Köpekleri. İstanbul'da Gündelik Hayat içinde . İstanbul: YKY.

Kalın, Y. (2016). İletişim Teknolojileri ve Dünya Görüşleri/Değer Yapıları. Değerler Bilançosu: Beyaz Kitap içinde . Konya: Çizgi.

Kaplan, M. (2000). Hikâye Tahlilleri. İstanbul: Dergâh.

Kaplan, Y. İ. (2018). Asır Sonu Edebiyatında Yoksulluğun İzlerini Aramak. 11 Mayıs 2019 tarihinde https://t24.com.tr/k24/yazi/serveti-funun-ve-yoksulluk, 1850 adresinden erişildi.

Kaymaz, K. (2008). Illk Türk Kadın Yazarlarından Emine Semiye Hanım, Hayatı Ve Eserleri. Marmara Üniversitesi, Türkiyat Araştırmaları Enstitüsü, Türk Dili ve Edebiyatı Ana Bilim Dalı.

Kılınçoğlu, D. T. (2017). İktisadi Düşünce Kaynağı Olarak Edebiyat. İktisat ve Diğer Bilimler içinde (ss. 231-266). İstanbul: İletişim.

Konstan, D. (2001). Pity Transformed. London: Duckworth.

Lee, V. ve Anstruther-Thomson, C. (1912). Beauty \& Ugliness and Other Studies in Psychological Aesthetics. London: John Lane.

Mardin, Ş. (1990). Türkiye'de İktisadi Düşüncenin Gelişmesi (1938-1918). Makaleler 2: Siyasal ve Sosyal Bilimler içinde . İstanbul: İletişim.

Mardin, Ş. (1991). Tanzimat ve Aydınlar. Türkiye'de Din ve Siyaset içinde . İstanbul: İletişim.

Mardin, Ş. (2013). Türk Modernleşmesi. İstanbull: İletişim.

McLuhhan, M. (2014). Gutenberg Galaksisi: Tipografik Insanın Oluşumu. (G. Ç. Güven, Çev.). İstanbul: YKY.

Mehmed Celal. (2001). Bir Kadının Hayatı. (A. Özalp, Haz.). İstanbul: Anka.

Mermutlu, B. (2004). Sosyal Düşünce Tarihimizde Şinasi. İstanbul: Kaknüs.

Mithat, A. (2018). Taaffüf. (A. Ş. Çoruk, Haz.). Ankara: TDK.

Nussbaum, C. M. (2001). Upheavals of Thought: The Intelligence of the Emotions. Cambridge: Cambridge University Press.

Orhan, O. (2017). Batı Medeniyeti Karşısında Ahmet Midhat Efendi. İstanbul: Dergâh.

Parla, J. (2003). Babalar ve Oğullar: Tanzimat Romanının Epistemolojik Temelleri. İstanbul: İletişim.

Ratcliffe, S. (2008). On Symphaty. Oxford: Clarendon Press.

Sağıroğlu, B. (2005). Nemide’ye Dair. B. Sağıroğlu (Haz.), Nemide içinde . İstanbul: Özgür.

Sarıdoğan, K. (2014). Dağarcık Dergisinin Çeviri Yazısı, Sistematik İndeksi ve Tahlili. Sakarya Üniversitesi Sosyal Bilimler Enstitüsü.

Sezai, S. P. (2017). Sergüzeşt. (Y. Çavdar, Haz.). Konya: Palet.

Sirrı, A. (1938). Edebiyat Tarihi Dersleri. İstanbul: Kanaat.

Spelman, E. V. (1997). Fruits of Sorrow: Framing Our Attention to Suffering. Boston: Beacon Press.

Sznaider, N. (1998). The Sociology of Compassion : Cultural Values, 2(1), 117-139.

Tahir, M. (2019). Netice-i Sa'y ve Kayınvalide. (Ç. Günay-Erkol, Haz.). Konya: Palet.

Tanpınar, A. H. (2008). XIX. Asır Türk Edebiyatı Tarihi. İstanbul: YKY.

Tarım, R. (2000). Mehmet Rauf'un Hayatı ve Hikâyeleri Üzerine Bir Araştırma. Ankara: Akçağ. 
Todorov, T. (2019). Aydınlanma Zihniyeti. (A. N. Bingöl, Çev.). İstanbul: BGST. Uşaklıgil, H. Z. (2006). Ferdi ve Şürekası. (S. Öz, Haz.). İstanbul: Özgür. Uşaklıgil, H. Z. (2015a). Sefile. (Ö. F. Huyugüzel, Haz.). İstanbul: Özgür. Uşaklıgil, H. Z. (2015b). Mai ve Siyah. (E. Doğan, Haz.). İstanbul: Özgür. 


\section{EXTENDED ABSTRACT}

Turkish literary critic and academic Jale Parla states that defining the Tanzimat culture as a "dilemmatic culture" has become a cliché. According to Parla (2003), "Until Beşir Fuad, it cannot be said that the Tanzimat writers were seriously affected by this kind of dilemma, and that they went back and forth between the poles of the dilemma" (p. 11). Parla explains why Orhan Okay's definition of "mülemma"11 is more appropriate for the dilemma of East and West in the Tanzimat by quoting: "One of the characteristics of the Tanzimat period is the mixing of the cultures, customs and traditions of Eastern and Western civilizations. Rather than a synthesis, it would be more appropriate to define it as a mülemma" (Orhan, 2017, p. 343). However, that the new genres that came after the classical Turkish poetry [divan], express not only an aesthetic preference but also an epistemological break and I argue that in the first literary works of the Turkish novel, the affect or emotion of pity cannot be explained by the "will of Allah" [Allah rlzasl]; but with the values of Enlightenment. This fact embodies the epistemological break mentioned above.

In this sense, as the Ottoman intellectual life became westernised, it is worth examining whether the "compassion" transformed into "pity". Ahmet Hamdi Tanpınar, XIX. Asır Türk Edebiyatı Tarihi [History of the $19^{\text {th }}$ Century Turkish Literature] (Tanpınar, 2008), shows the emergence of a new morality by giving an example of Ahmet Mithat's Mihnetkeşan novella in Letaif-i Rivayat. According to Tanpınar, in Mihnetkeşan, Ahmet Mithat approaches the sex worker with a feeling of pity instead of judging them following the customs of his time, and thus "[t]he pity goes beyond a morality rooted in religion" (p. 266). Moreover, Mehmet Kaplan, argues that feeling of pity was imported from the West for the first time in the short story of Samipaşazade Sezai titled "Pandomima": "The human interest and pity felt towards an ordinary person also came to Turkish literature from the West" (Kaplan, 2000, pp. 24-25). Based on the two quotations above, it is possible to say that a new emotion of pity has begun to appear in Turkish literature along with the new genres, however, focusing on the ontological difference between the feelings of pity and compassion would make the above judgments more comprehensible.

The difference between the words pity and compassion in terms of origin is also reflected in the semantic depths of these concepts. Spelman (1997) distinguishes compassion as suffering "with others" and pity as suffering "for others". Hannah Arendt also touches on the ontological difference between pity and compassion in her book On Revolution (Arendt, 2017), in which she discusses the pioneering values of the idea of revolution through the American and French Revolutions. Arendt agrees that pity is a pure emotion/affection, and compassion is another emotion that necessitates action under the influence of this affect. "[C]ompassion is one of the passions, and pity is a sentiment." (p. 115).

In addition, there is a feeling of pity in classical Turkish poetry. The lover, who degrades himself in the lowest position in the face of his beloved such as a servant, a dead man, or a dog lying on the threshold of his beloved, feels self-pity on the one hand and begs for mercy on the other. However, the lover's pity for himself due to the role he has voluntarily assigned to himself can also be considered as a kind of masochism.

Poverty is one of the most important sources that arouse pity along with slavery of women [esaret] in $19^{\text {th }}$ century Turkish novels. However, Ahmet Mithat, who is the most important author of this period in terms of both the effect and the number of works, focuses on the middle class, not the poverty of poor people but the adventure of enrichment of the middle class. In Ahmet Mithat's fiction, the misery caused by poverty is mostly seen in his novels which take place in Europe or Ottoman lands among its non-Muslim community. Abundant material on pity-arousing poverty is generally found in Hüseyin Rahmi, in the novels of Mehmed Celal, who is very popular at his time but neglected today, and in the works of Halit Ziya, who is accused of being socially isolated. For example, the homeless Turkish girl we never saw in the fiction of Ahmet Mithat, appears in Halit Ziya's Sefile [The Miserable Girl] for the first time. For Mazlume, there is not a single person she can be sure of his "compassion". Mazlume, who knocked on the door of a neighbour in desperation, stays here for only fifteen days but afterwards no other neighbour wants to take her into her home. "Isn't it enough for a thirteen-year-old child to suffer such misfortune as not having a father or a mother?" (p. 31). Moreover, no hand reached Mazlume, who spent a long night in the courtyard of the mosque after her two weeks of accommodation. Even though Mazlume had slept on a mat in the courtyard of the mosque for ten days, she could not see a "benevolent, merciful face". These poverty and economic problems which arouse pity are at the center of Halit Ziya's other novels (Ferdi ve

\footnotetext{
${ }^{11}$ 1. It refers to a mixed situation. "(A poem) composed half in one language and half in another. 2. party-gilt, party-coloured (Redhouse, 1978, p. 948).
} 
Şürekasi, Mai ve Siyah) and his short stories as well.

Another point that draws the attention to this pattern is that situations that arouse "compassion" correspond with "pity". Characters who fit for at least two of Aristotle's three conditions for feeling pity which explained in Rhetorics (Aristoteles, 2000, p. 116) -not deserving evil, the seriousness of evil, a misery that can happen to others- are not supported by any religious references. The feeling of compassion takes its source from religious references and this feeling must be complemented by an action. On the other hand, the feeling of pity can be defined as the more secular and humanist motives of compassion. In this respect, it is possible to trace the historical background of pity and compassion in Western literature, as it is shown in detail in this study. In the focus of the $19^{\text {th }}$ century Turkish novel, Kaplan's abovementioned argument that the pity was imported from the West should be read regarding Tanpınar's claims on the pity which "goes beyond a morality rooted in religion" (p. 266). Without denying the existence and repeated emphasis on compassion and social solidarity in the religion of Islam, it is of great importance to put emotion in $19^{\text {th }}$ century Turkish novel in its place by considering the existential difference between pity and compassion. In the first literary works of the Turkish novel, it is seen that the emotion or affect of pity takes its source from the values of Enlightenment rather than a compassion motivated by religious motivations. 